\title{
Juvenile Life Without the Possibility of Parole: Constitutional But Complicated
}

Christopher A. Mallett

Cleveland State University, c.a.mallett@csuohio.edu

Follow this and additional works at: https://engagedscholarship.csuohio.edu/clsowo_facpub

Part of the Criminal Law Commons, Juvenile Law Commons, Social Control, Law, Crime, and Deviance Commons, and the Social Work Commons

How does access to this work benefit you? Let us know!

\section{Publisher's Statement}

(c) 2013 Elsevier. "Voluntary posting by an author on open websites operated by the author or the author's institution for scholarly purposes, as determined by the author, or (in connection with preprints) on preprint servers."

\section{Recommended Citation}

Mallett, Christopher A., "Juvenile Life Without the Possibility of Parole: Constitutional But Complicated" (2013). Social Work Faculty Publications. 11.

https://engagedscholarship.csuohio.edu/clsowo_facpub/11

This Article is brought to you for free and open access by the School of Social Work at EngagedScholarship@CSU. It has been accepted for inclusion in Social Work Faculty Publications by an authorized administrator of EngagedScholarship@CSU. For more information, please contact library.es@csuohio.edu. 


\title{
Juvenile life without the possibility of parole: Constitutional but complicated
}

\author{
Christopher A. Mallett* \\ School of Social Work, Cleveland State University, 2121 Euclid Avenue, \#CB324, Cleveland, OH 441218-2214, United States
}

\section{Introduction}

Over the past decade the Supreme Court has categorically narrowed the most severe punishments for youthful offenders convicted of serious crimes, restricting the punishments for these adolescents including the death penalty and life imprisonment without the possibility of parole (LWOP) for non-homicide crimes. These decisions have mirrored the steady, yet uneven, shift within juvenile justice from a punishment to rehabilitative paradigm. This continued movement toward rehabilitation is necessary because almost all low-level and many seriousoffending adolescents can be successfully diverted from the juvenile and adult criminal justice systems. Of concern, though, is the ongoing transfer of adolescents, often direct and without a judicial hearing, from the juvenile to the adult courts in many states, and potential for LWOP sentences after the Miller v. Alabama Supreme Court decision. While the Court now requires individualized judicial sentencing for these adolescents, finding that mandatory LWOP state laws are unconstitutional, this sentence will most probably still be the outcome in punitively-focused jurisdictions. These LWOP sentences for adolescents who have committed a homicide are rarely in the individuals, courts, or societies' best interests.

In making the argument that all juvenile LWOP sentences should be unconstitutional - in that a future parole hearing should at least be an option - this paper first reviews the Supreme Court doctrine that has minimized categorical sentencing laws for extreme youthful offender punishments and requirements for mitigating evidence reviews; second, discusses the state transfer and sentencing laws

\footnotetext{
* Tel.: + 12164237514 .

E-mail address: c.a.mallett@csuohio.edu.
}

that will continue to allow a juvenile LWOP sentence for homicide post Miller; third, provides a profile of serious youthful offenders and a number of their most difficult experiences and problems that gravely increase the risk of involvement in criminal offending; and fourth, advocates for the use of effective preventative programming and treatments that improve serious youthful offender outcomes, including those who have committed homicide, by addressing these difficulties. Through earlier interventions with very at-risk children and adolescents it is possible to divert most from offending and harmful behaviors. Even for those that are not diverted and commit homicide, the use of life sentences to prison is simply draconian for this extinguishes not only any possibility of an offender's rehabilitation, but also any hope. In addition, the Supreme Court has a long history of decisions that find adolescent offenders different from adult offenders and that age itself and its corresponding limitations to be mitigating factors. An alternative that allows at least a chance for a parole hearing is warranted. This does not guarantee or justify a prison release, but would allow an opportunity for adolescents who have committed homicide crimes, and are sentenced to die in prison, to show the ability to change or rehabilitate.

\section{Supreme Court doctrine}

\subsection{Categorical sentencing bans}

The Constitution's Eighth Amendment requires punishment to be proportioned to the offense (Roper $v$. Simmons, 2005, p. 560). A key factor in this proportionality determination is the culpability of the offender (Atkins v. Virginia, 2002, p. 319; Edmund v. Virginia, 1982, pp. 797-802; Roper v. Simmons, 2005, pp. 569-570). Since 2002, the 
Court in Atkins v. Virginia, Roper v. Simmons, Graham v. Florida (2010), and Miller v. Alabama (2012) narrowed the available use of the most severe criminal punishments for four categories of offenders, finding these sentences violated the Amendment's Cruel and Unusual Punishment Clause.

In the Court's first decision, Atkins, it was found that youthful (and adult) offenders with lower intellectual functioning could not be sentenced to death because their disabilities limited impulse control and judgment abilities, "[t]hey do not act with the level of moral culpability that characterizes the most serious adult criminal conduct." (Atkins v. Virginia, 2002, p. 305). The Court further reasoned that the use of this severe punishment neither afforded retribution for the offender's act nor deterrence (Atkins $v$. Virginia, 2002, p. 311). This decision was important in providing serious youthful (and adult) offenders with significant mental retardation and developmental disabilities respite from the death penalty.

In the second decision, Roper, the Court found youthful offenders less culpable for similar impulse control reasons, among others, but went further to find adolescence itself a mitigating factor (Roper $v$. Simmons, 2005, p. 557). ${ }^{1}$ This was not the first Court holding or commentary on juvenile offender culpability, for in Johnson $v$. Texas (1993), the Court stated: "the signature qualities of youth are transient; as individuals mature, the impetuousness and recklessness that may dominate in younger years can subside" (p. 368). The Court found relevant differences between those under 18 years of age and adults so consequential as to not classify adolescents among the worst offenders. ${ }^{2}$ These differences included an underdeveloped sense of responsibility leading to impetuous actions as well as a lack of maturi$\mathrm{ty}^{3}{ }^{3}$ lessened character development, ${ }^{4}$ and vulnerability to negative influences and outside peer pressure ${ }^{5}$ (Roper v. Simmons, 2005, p. 557). For these reasons "almost every State prohibits those under 18 years of age from voting, serving on juries, or marrying without parental consent" (Roper v. Simmons, 2005, p. 557). The juvenile death penalty was thus abolished, though these individuals were resentenced to LWOP.

In the third decision, Graham, the Court found that sentencing non-homicide youthful offenders to LWOP was unconstitutional. In so holding, the Court reinforced and relied upon its Roper decision in reiterating that youthful offenders are different from adult offenders, and that these characteristics mean that "[i]t is difficult even for expert psychologists to differentiate between the juvenile offender whose crime reflects unfortunate yet transient immaturity, and the rare juvenile offender whose crime reflects irreparable corruption" (Graham v. Florida, 2010, p. 22). The Court further found that "developments in psychology and brain science continue to show fundamental differences between juvenile and adult minds" (Graham v. Florida, 2010, p. 24). The Court decision, however, did not extend this constitutional protection to youthful offenders sentenced to LWOP for homicide crimes.

This constitutional protection from LWOP for youthful offenders convicted of homicide was extended in the fourth decision, Miller. The Court furthered the reasoning from Roper and, more significantly from Graham, in finding that a youthful offender convicted of

\footnotetext{
1 "The relevance of youth as a mitigating factor derives from the fact that the signature qualities of youth are transient; as individuals mature, the impetuousness and recklessness that may dominate in younger years can subside."

2 "The reality that juveniles still struggle to define their identity means it is less supportable to conclude that even a heinous crime committed by a juvenile is evidence of irretrievably depraved character."

3 " $[\mathrm{A}]$ lack of maturity and an underdeveloped sense of responsibility are found in youth more often than in adults and are more understandable among the young. These qualities often result in impetuous and ill-considered actions and decisions."

4 "[T]he character of a juvenile is not as well formed as that of an adult. The personality traits of juveniles are more transitory, less fixed."

5 "[Y] outh is more than a chronological fact. It is a time and condition of life when a person may be most susceptible to influence and to psychological damage. This is explained in part by the prevailing circumstance that juveniles have less control, or less experience with control, over their own environment."
}

homicide and sentenced by a mandatory state statute to LWOP was unconstitutional. The Court determined that these mandatory laws "run afoul of our cases' requirement of individualized sentencing for defendants facing the most serious penalties" (Miller v. Alabama, 2012, p. 13).

\subsection{Mitigating evidence}

The Supreme Court has increasingly required the review of youthful (and adult) offenders' backgrounds, characteristics, experiences, and difficulties before allowing some of the more severe judicial sentencing punishments. The Court held, in 1972, the death penalty to be unconstitutional due to arbitrary and capricious state sentencing standards (Furman v. Georgia, 1972). When the Court reestablished the death penalty as constitutional four years later, it directed the sentencing authority to consider relevant mitigating circumstances to the offense and a range of factors about the individual defendant (Gregg $v$. Georgia, 1976; Proffitt v. Florida, 1976). In striking down mandatory capital sentencing statutes that existed prior to 1972, the Court found that the flaw was the failure to permit the presentation of mitigating circumstances (Woodson v. California, 1976). "[T]he Eighth Amendment," explained the Court, "requires consideration of the character and record of the individual ... as a constitutionally indispensable part of the process of inflicting the penalty of death" (Woodson v. California, 1976, p. 303). ${ }^{6}$

Beginning with Lockett v. Ohio (1978) the Court recognized that in order to support individualized sentencing requirements in capital cases the sentencing authority must be permitted to consider any aspect of a defendant's character or record and any of the offense circumstances. In Eddings v. Oklahoma the Court accepted the Lockett plurality's approach and emphasized that Lockett requires the "sentencer to listen" (Eddings v. Oklahoma, 1982, p. 115) and that troubled childhood histories must be considered as a mitigating factor. Subsequently, the Court found that jury instructions may not limit jury consideration of these mitigating circumstances a significant step in having all parties be aware of the defendant's background and circumstances (Hitchcock v. Dubber, 1987). Also, the Court found that the defendant's background and character are relevant because of society's belief that a disadvantaged background, emotional difficulties, or mental problems may diminish offenders' moral culpability (California v. Brown, 1976). Indeed, the Court has posited that " $[t]$ he sentence imposed at the death penalty stage should reflect a reasoned moral response to the defendant's background, character, and crime" (Woodson v. California, 1976, p. 304), and must consider both the tangibles and intangibles of the defendant (Caldwell v. Mississippi, 1987). In some cases, evidence of drug abuse, brain damage, and poverty must be reviewed by the sentencing authority (Hitchcock $v$. Dubber, 1987).

It is unequivocal that evidence from childhood difficulties must be presented to the sentencing authority (Williams $v$. Taylor, 2000). The Court in Williams determined that the following evidence should be considered at sentencing of defendants: child borderline mental retardation, child physical abuse, parent imprisonment for child neglect, and reunification of the child with the abusive parent post prison release. In this particular case, the Court faulted the absence of jury instructions informing the jury that it could consider and give effect to the defendant's mental retardation and history of abuse (Williams v. Taylor, 2000, pp. 370-371).

And most recently in Miller, the Court went further stating that " $[\mathrm{m}]$ andatory life without parole for a juvenile precludes consideration of his

\footnotetext{
${ }^{6}$ The Court continued that "without this consideration, the possibility of compassionate or mitigating factors could not be reviewed in light of the frailties of humankind. Fixed death penalty sentencing guidelines treat human beings as members of a faceless, undifferentiated mass to be subjected to the blind infliction of the penalty of death."
} 
chronological age and its hallmark features - among them, immaturity, impetuosity, and failure to appreciate risks and consequences. It prevents taking into account the family and home environment that surrounds him - and from which he cannot usually extricate himself no matter how brutal or dysfunctional" (Miller v. Alabama, 2012, p. 15).

\subsection{Juvenile LWOP today}

The law today allows the sentencing of youthful offenders convicted of homicide to LWOP, but only after the sentencing court has investigated and reviewed the adolescent's mitigating evidence, involvement in the offense, and related matters. Specifically, a sentencing authority must consider the adolescent's age and impact on maturity and appreciation of consequences, the adolescent's family and home environment, the offense circumstances including involvement level and influence of peers, the adolescent's level of sophistication in dealing with the adult criminal justice system, and the possibility for rehabilitation. This mitigation investigation should be thorough and identify important developmental, family, maltreatment, mental health, and other related disability circumstances that the adolescent suffers or has suffered from; and in particular, those that impacted the commission of the crime (Miller v. Alabama, 2012).

The Court went further in stating that they believed that "appropriate occasions for sentencing juveniles to this harshest of penalty will be uncommon" (Miller v. Alabama, 2012, p. 17). This prognosticated outcome may become a reality, but there remain obstacles. There is no guarantee that important evidence of an adolescent's family difficulties, mental health problems, learning deficiencies, or other mitigating evidence has been identified or addressed prior to or concurrent with criminal court involvement. There is significant concern for the underreporting of family maltreatment and dysfunction within child welfare (Administration for Children and Families, 2011), the stigma and avoidance of mental health disorder diagnoses and subsequent treatment (Kessler et al., 2005; Substance Abuse and Mental Health Services Administration, 2008a), the hidden or difficult to identify learning and academic disabilities (Leone \& Weinberg, 2010), among others. If important mitigating evidence is not uncovered and utilized within the judicial process, then the right attached in Miller is not guaranteed. In addition, it is quite possible that many sentencing authorities are not aware of the strong links from these difficulties to serious youthful offending, and may minimize their importance.

\section{State juvenile LWOP statutes}

A sentence of LWOP for a youthful offender was available in 32 states prior to the Miller decision. For an adolescent to receive a lifetime imprisonment sentence, there are two steps involved: first, the adolescent is transferred from juvenile to criminal court jurisdiction; and, second, post conviction, a life sentence is ordered. A majority of youthful offenders transferred to criminal courts over the past two decades have been through statutory exclusion waivers, automatically excluding certain youthful offenders from the juvenile courts' original jurisdiction, with specified offense and age criteria - most often older adolescents, ages 15 to 17, for homicide, rape, and other serious crimes (Green, 2005; Redding, 2010). By 2000, only 13\% of adolescents tried in the criminal courts had received a judicial transfer hearing, being automatically transferred through these exclusion waivers (Human Rights Watch, 2009); little has changed in the transfer laws over the past decade (Griffin, 2011). There are, on average since 2001, over 1500 adolescents who commit a homicide each year in the United States (Puzzanchera \& Kang, 2011).

State laws that direct juvenile transfer and LWOP sentences can be separated into three categories. The following three tables for each category include: the state; specific state code or statute for both the transfer and sentencing laws; age minimum or range by which a youthful offender can be transferred from juvenile to criminal court; and how a LWOP sentence is handled, be it discretionary, mandatory, or different via the type of crime.

The first category includes states that allow a LWOP sentence for a homicide to be determined with sentencer discretion, whereby the sentencing authority is able to review and hold hearings to consider and weigh mitigating and aggravating evidence (see Table 1: Arizona, California, Hawaii, Idaho, Maryland, Mississippi, Nevada, New Hampshire, North Dakota, Oklahoma, Tennessee). These state laws are constitutional after Miller if the sentencing court is required to review the adolescents' mitigating evidence and the offense circumstances.

The second category includes states where the transfer of the adolescent to criminal court is discretionary but the LWOP sentence is mandatory for a homicide. Thus allowing the possibility of a review hearing prior to transferring the adolescent to criminal court, but if transferred and convicted, the LWOP sentence automatically applied (see Table 2: Alabama, Arkansas, Iowa, Michigan, Minnesota, Missouri, Rhode Island, South Carolina). These sentencing laws, though not the transfer laws, are unconstitutional after Miller.

Table 1

LWOP allowed after review of mitigating and aggravating evidence.

\begin{tabular}{|c|c|c|}
\hline State & Statute & Law summary \\
\hline Arizona & Ariz. Rev. Stat. Ann. §13-701-706; 752; §501(A)-(B) (2012) & Juvenile transfer (ages 15-17) is mandatory; LWOP is discretionary \\
\hline California & Cal. Penal Code Ann. §190.05(a--i); §209 (2011) & Juvenile transfer (age 16) is discretionary; LWOP is discretionary \\
\hline Hawaii & Haw. Rev. Stat. §571-22(d); §706-656(1) (Lexis 2012) & $\begin{array}{l}\text { Juvenile transfer (no minimum age) is discretionary for these same offenses; } \\
\text { LWOP for first-degree murder or heinous second-degree murder is discretionary }\end{array}$ \\
\hline Idaho & Idaho Code Ann. §18-4004; §20-508; §20-509(3)-(4) (2011) & $\begin{array}{l}\text { Juvenile transfer (no minimum age) is mandatory for certain offenses; } \\
\text { LWOP for first-degree murder is discretionary }\end{array}$ \\
\hline Maryland & $\begin{array}{l}\text { Md. Code Ann., Crim. Law §2-202, 2-203, 2-304; } \\
\text { Md. Code Ann., Cts. and Jud. Proc. §3-8A-06 (Lexis 2012) }\end{array}$ & $\begin{array}{l}\text { Juvenile transfer (no minimum age) for murder is discretionary; } \\
\text { LWOP is discretionary }\end{array}$ \\
\hline Mississippi & Miss. Code Ann. §97-3-21; §43-21-151(a), 43-21-157(8) (Lexis 2012) & $\begin{array}{l}\text { Juvenile transfer (age 13) is mandatory for murder; } \\
\text { LWOP for murder is discretionary }\end{array}$ \\
\hline Nevada & Nev. Rev. Stat. Ann. §200.030 §62B.330 (2012) & $\begin{array}{l}\text { Juvenile transfer (age } 8 \text { ) for murder is mandatory; } \\
\text { LWOP for murder in first degree is discretionary }\end{array}$ \\
\hline New Hampshire & N.H. Rev. Stat. Ann. §630:1-a; §628:1 (2011) & $\begin{array}{l}\text { Juvenile transfer (age 13) is discretionary; } \\
\text { LWOP for murder in first degree is discretionary }\end{array}$ \\
\hline North Dakota & N.D. Cent. Code §12.1-32-01; §12.1-04-01 (2011) & Juvenile transfer (age 14) is discretionary; LWOP is discretionary \\
\hline Oklahoma & $\begin{array}{l}\text { Okla. Stat. Ann. tit. 21, §701.9 (West } 2010 \text { and Supp. 2008); } \\
\text { tit. 10, §7306-1.1 (West 2010) }\end{array}$ & $\begin{array}{l}\text { Juvenile transfer (age 13) for murder is mandatory; } \\
\text { LWOP for first-degree murder is discretionary }\end{array}$ \\
\hline Tennessee & $\begin{array}{l}\text { Tenn. Code Ann. } \S 39-13-202,39-13-204 \\
\S 37-1-134 \text { (a)(1) (Lexis 2012) }\end{array}$ & $\begin{array}{l}\text { Juvenile transfer (no age limit) for first-degree murder is mandatory; } \\
\text { LWOP for first-degree murder is discretionary }\end{array}$ \\
\hline
\end{tabular}


Table 2

Transfer is discretionary but LWOP is mandatory (sentencing law is now unconstitutional).

\begin{tabular}{|c|c|c|}
\hline State & Statute & Law summary \\
\hline Alabama & Ala. Code §13A-5-39-52; §13A-15-34 (2011) & $\begin{array}{l}\text { Juvenile transfer (age } 14 \text { ) is discretionary; } \\
\text { LWOP for murder or for Felony A habitual offender is mandatory }\end{array}$ \\
\hline Arkansas & Ark. Code §9-27-318(b)(2009); §5-4-104 (2012) & $\begin{array}{l}\text { Juvenile transfer (age } 14 \text { ) is discretionary; } \\
\text { LWOP for capital murder is mandatory }\end{array}$ \\
\hline Iowa & Iowa Code Ann. §902.1; §232.45(6)(a) (West 2010) & $\begin{array}{l}\text { Juvenile transfer (age } 14 \text { ) is discretionary; } \\
\text { LWOP for Class A Felony is mandatory }\end{array}$ \\
\hline Michigan & Mich. Comp. Laws §712A.4; §769.1; §791.234(6); §791.244 (2012) & $\begin{array}{l}\text { Juvenile transfer (no minimum age) is discretionary; } \\
\text { LWOP for first-degree murder is mandatory } \\
\text { (though Governor clemency available after } 10 \text { years served) }\end{array}$ \\
\hline Minnesota & Minn. Stat. Ann. §609.106; §260.125 (2012) & $\begin{array}{l}\text { Juvenile transfer (age 14) is discretionary; } \\
\text { LWOP for first-degree murder and other heinous crimes is mandatory }\end{array}$ \\
\hline Missouri & Mo. Ann. Stat. §565.020; §211.071 (West 2011) & $\begin{array}{l}\text { Juvenile transfer (age } 12 \text { ) is discretionary; } \\
\text { LWOP for first-degree murder is mandatory }\end{array}$ \\
\hline Rhode Island & R.I. Gen. Laws §12-19.2-4; §14-1-7 §11-23-2; §12-19-11 (2011) & $\begin{array}{l}\text { Juvenile transfer (no minimum age) is discretionary; } \\
\text { LWOP for first-degree murder is mandatory }\end{array}$ \\
\hline South Carolina & S.C. Code Ann. §17-25-45; §20-7-7605(6) (2011) & $\begin{array}{l}\text { Juvenile transfer (no minimum age) is discretionary; } \\
\text { LWOP for murder is mandatory only with prior conviction }\end{array}$ \\
\hline
\end{tabular}

The third category includes states where the transfer of the adolescent to criminal court is mandatory and the LWOP sentence was mandatory for a homicide, thus not allowing any review hearing either at transfer or sentencing (see Table 3: Connecticut, Delaware, Florida, Illinois, Louisiana, Massachusetts, Nebraska, North Carolina, Pennsylvania, South Dakota, Texas, Virginia, Washington). These sentencing laws, though not the transfer laws, are also unconstitutional after Miller.

It is these last two mandatory sentencing state law categories (Tables 2 and 3) that are now unconstitutional after the Miller decision. The individuals so sentenced are entitled to a sentencing authority review, now including mitigating and offense involvement evidence.

The Supreme Court, in Miller, limited the use of juvenile LWOP sentences and asked as part of their analysis if "objective indicia of society's standards, as expressed in legislative enactments and state practice", show a national consensus against a sentence for a particular class of offenders (Graham v. Florida, 2010, p. 10). Today, 21 states (Tables 2 and 3) must statutorily amend their juvenile LWOP sentencing laws because of Miller, while 11 state sentencing laws (Table 1) are constitutional as written. When recognizing that the Miller decision has required a minority of states ( 21 of 50 ) to amend their sentencing laws for this population, and that the remaining 18 states do not even allow this sentence, LWOP punishment already is in fact unusual. In other words, a national consensus has already emerged against this most severe punishment for youthful offenders - a life sentence without even the possibility for a parole hearing.

The importance, prevalence, and impact of serious youthful offenders' maltreatment histories, mental health disorders, and learning disabilities are next reviewed; representing some of the mitigating evidence required after (and through earlier Supreme Court decisions, before) Miller; evidence that links these difficulties to serious offending, and, at times, homicide.

\section{Serious youthful offender profile: required mitigating evidence}

Most children and adolescents do not suffer from nor experience maltreatment victimizations (or extreme family dysfunction), learning disabilities, or mental health problems. If a child or adolescent does have one of these difficulties, it most often is a singular experience

Table 3

Transfer and LWOP sentence is mandatory (sentencing law is now unconstitutional).

\begin{tabular}{|c|c|c|}
\hline State & Statute & Law summary \\
\hline Connecticut & Conn. Gen. Stat. §53a-35b; §46b-127 (2012) & $\begin{array}{l}\text { Juvenile transfer (age } 14 \text { ) is mandatory; } \\
\text { LWOP for capital murder is mandatory }\end{array}$ \\
\hline Delaware & Del. Code Ann. Tit. $11 \S 4209$; Tit. $10 \S 1010,1011$ (2012) & $\begin{array}{l}\text { Juvenile transfer (no minimum age) is mandatory, } \\
\text { though juvenile can request a hearing; } \\
\text { LWOP for first-degree murder is mandatory }\end{array}$ \\
\hline Florida & Fla Stat. Ann. §775.082; §985.225 (2012) & $\begin{array}{l}\text { Juvenile transfer (no minimum age) is mandatory; } \\
\text { LWOP for murder is mandatory }\end{array}$ \\
\hline Illinois & 730 Ill. Comp. Stat. Ann. 5/5-8-1; 405/5-130 (4)(a) (West 2011) & $\begin{array}{l}\text { Juvenile transfer (age 13) is mandatory; } \\
\text { LWOP for first-degree murder is mandatory (with one aggravating factor) }\end{array}$ \\
\hline Louisiana & La. Rev. Stat. Ann. §14:30.1; La. Child Code Ann. art. 305 (2011) & $\begin{array}{l}\text { Juvenile transfer (age } 15 \text { ) for these offenses is mandatory; } \\
\text { LWOP for first- and second-degree murder is mandatory }\end{array}$ \\
\hline Massachusetts & Mass Gen. Laws ch. 119, 72B; §74; id., ch. 265, §2 (2012) & $\begin{array}{l}\text { Juvenile transfer (age 14) for these offenses is mandatory; } \\
\text { LWOP for first- or second-degree murder is mandatory }\end{array}$ \\
\hline Nebraska & Neb. Rev. Stat. §43-247; §28-105; §29-2522 (2011) & $\begin{array}{l}\text { Juvenile transfer (no minimum age) for first-degree murder is mandatory; } \\
\text { LWOP for first-degree murder is mandatory }\end{array}$ \\
\hline North Carolina & N.C. Gen. Stat. §14-17; §7B-2200 (2011) & $\begin{array}{l}\text { Juvenile transfer (age 13) for Class A felony (murder included) is mandatory; } \\
\text { LWOP for murder in first degree is mandatory }\end{array}$ \\
\hline Pennsylvania & $\begin{array}{l}18 \text { Pa. Cons. Stat. Ann. §1102, 9711; } \\
61 \text { Pa. Cons. Stat. Ann. §6137; §6355(e) (2011) }\end{array}$ & $\begin{array}{l}\text { Juvenile transfer (no minimum age) for these offenses are mandatory; } \\
\text { LWOP for first- or second-degree murder is mandatory }\end{array}$ \\
\hline South Dakota & S.D. Codified Laws §22-6-1; §24-15-4; §26-11-3.1 (2012) & $\begin{array}{l}\text { Juvenile transfer (age } 16 \text { ) is mandatory; } \\
\text { LWOP for Class A felonies is mandatory }\end{array}$ \\
\hline Texas & Tex. Fam. Code Ann. §12.31 (2011) & $\begin{array}{l}\text { Juvenile transfer (age 17) for capital murder is mandatory; } \\
\text { LWOP for capital murder is mandatory }\end{array}$ \\
\hline Virginia & Va. Code Ann §18.2-10; §16.1-269.1; §53.1-151(B1) (2012) & $\begin{array}{l}\text { Juvenile transfer (age } 14 \text { ) is mandatory; } \\
\text { LWOP for murder is mandatory with } 3 \text { felony convictions } \\
\text { for murder, rape, or robbery }\end{array}$ \\
\hline Washington & Wash. Rev. Code Ann. §10.95.030; §13.04.030 (2011) & $\begin{array}{l}\text { Juvenile transfer (age 15) for serious violent offense is mandatory; } \\
\text { LWOP for aggravated murder in the first degree is mandatory }\end{array}$ \\
\hline
\end{tabular}


(Mallett, 2003). Only a small percentage (less than one percent) of children and adolescents will be a victim of maltreatment, have a learning disability (three to four percent), be diagnosed with a serious mental health disorder (five to nine percent), or have an active substance abuse problem (4 to 5\%) (New Freedom Commission on Mental Health, 2003; Substance Abuse and Mental Health Services Administration, 2008a, 2008b; U.S. Department of Education, 2010; U.S. Department of Health and Human Services, 2010). However, reviews of detained and incarcerated youthful offenders have found significantly higher incidences of these experiences within this population - from two (some mental health disorders) to as many as 60 times (for maltreatment victimization, see Table 4) the rates found in the child and adolescent population (Leone \& Weinberg, 2010; Mears \& Aron, 2003; Teplin et al., 2006; Washburn et al., 2008).

Maltreatment victimization rates are the substantiated cases of abuse and neglect as reported by the U.S. Department of Health and Human Services; learning disabilities and emotional disturbances are the identified students who are under an individualized education plan as directed by the Individuals with Disabilities Education Act (U.S. Department of Education, 2010); and mental health/substance abuse disorders are diagnosed psychiatric problems as defined by the Diagnostic and Statistical Manual of Mental Health Disorders (American Psychiatric Association, 2000). These problems and difficulties are much more common in the serious youthful offender population (Table 2, 2nd column). This compares to the adolescent population (ages 12 to 17) in the United States, where significantly lower rates are found across all problem and difficulty areas (Table 2, 3rd column). The range in prevalence rates for detained and incarcerated youthful offenders reflects the difference from detention center populations (lower rates) to state-run juvenile justice incarceration facilities (higher rates). This is noteworthy because many adolescents who commit homicide have a serious offending background, often including placement in a state-run juvenile justice incarceration facility (Farrington, Loeber, \& Berg, 2012; Heide, Roe-Sepowitz, Solomon, \& Chan, 2011).

\subsection{Link to delinquency and serious offending}

The small number of adolescents who commit serious offenses often have long histories of delinquency beginning at an early age and are most at risk to continue offending patterns into adulthood (Degue \& Widom, 2009; Howell, 2003; Snyder, 1998). As is evident from the detained and incarcerated youthful offender population, this group is disproportionately impacted by maltreatment and related trauma, mental health problems, and learning/academic disabilities. These difficulties not only are important mitigating evidence that should be reviewed by a sentencing authority, but also are often linked to the offending and delinquent behaviors.

Table 4

Maltreatment and education/mental health problem prevalence rates.

\begin{tabular}{lll}
\hline Type & $\begin{array}{l}\text { Detained/incarcerated } \\
\text { youthful offender } \\
\text { population (\%) }\end{array}$ & $\begin{array}{l}\text { Adolescent } \\
\text { population (\%) }\end{array}$ \\
\hline $\begin{array}{l}\text { Maltreatment victimization } \\
\text { Special education disabilities } \\
\quad \text { learning disabilities and }\end{array}$ & $26-60$ & $1^{\text {a }}$ \\
$\quad$ emotional disturbances) & $4-6^{\mathrm{b}}$ \\
$\quad \begin{array}{l}\text { Serious mental health disorders } \\
\text { Substance abuse }\end{array}$ & $25-70$ & $5-9^{\mathrm{c}}$ \\
\hline a U.S. Department of Health and Human Services (2010). & $3-5^{\mathrm{d}}$ \\
b Mallett (2011), U.S. Department of Education (2010). \\
c Substance Abuse and Mental Health Services Administration (2008b), U.S. Surgeon \\
General (2001). \\
d Substance Abuse and Mental Health Services Administration (2010).
\end{tabular}

\subsubsection{Maltreatment victimization}

Children and adolescents who have been maltreated are more likely to engage in delinquent activities and more serious offending behaviors, compared to children and adolescents without a maltreatment history (Loeber \& Farrington, 2001; Verrecchia, Fetzer, Lemmon, \& Austin, 2010; Yun, Ball, \& Lim, 2011). Due to the significant differences in outcomes of offending acts (e.g., arrest, conviction, delinquency adjudication), including whether official records or youthful offender selfreports were used, the link between maltreatment and delinquency may be underestimated (Maxfield, Weiler, \& Widom, 2000).

All three maltreatment types (physical abuse, sexual abuse, and neglect) have been linked to later antisocial behavior, violent crimes, and court involvement (Grogan-Kaylor, Ruffolo, Ortega, \& Clarke, 2008; Lemmon, 2009; Yun et al., 2011), even in the presence of other risk factors (Loeber \& Farrington, 2001; Widom \& Maxfield, 2001). Research is clear that repeated maltreatment, no matter the type, has a key impact on youthful offending behavior (Arata, LanghinrichsenRohling, Bowers, \& O'Brien, 2007). Such repeat victimization predicts the initiation, continuation, and severity of delinquent acts, and is associated with serious, chronic, and violent offending behaviors (Hamilton, Falshaw, \& Browne, 2002; Smith \& Thornberry, 1995).

While findings are mixed, age of maltreatment onset appears related to youthful offending, though both early childhood (before age five) maltreatment (Manly, Kim, Rogosch, \& Cicchetti, 2001) as well as adolescent age maltreatment (Johnson-Reid \& Barth, 2000) have been found linked. Further, in two clinical studies of youthful offenders who committed homicide, female offenders had higher rates of childhood abuse (and mental health problems) than male offenders (RoeSepowitz, 2009); however, in the second study, male and female offenders had comparable rates of physical and sexual abuse as children (Zagar, Isbell, Busch, \& Hughes, 2009).

\subsubsection{Learning disabilities}

Children at risk for academic failure in elementary school often have unidentified learning problems; those who fail are at increased risk for later offending behaviors (Hawkins et al., 2000). It is also speculated that adolescents with unidentified learning disabilities may be disproportionately represented among those who are suspended, expelled, and/or drop out of high school (Keleher, 2000). Suspensions, expulsions and dropping out are all risk factors for delinquent and criminal activities, often serious offending (Hawkins et al., 2000; Sum, Khatiwada, McLaughlin, \& Palma, 2009).

Yet even for those adolescents who have been identified with learning disabilities their risk for delinquency is still higher. Reviews have found that adolescents with learning disabilities compared to those adolescents without such learning disabilities have two to three times greater risk of being involved in offending activities, as well as higher offending recidivism rates (Matta-Oshima, Huang, Jonson-Reid, \& Drake, 2010; Wang, Blomberg, \& Li, 2005). This link from the schools to the juvenile courts, and in particular detention and incarceration facilities, has gained the attention and concern of many policy makers and stakeholders. This pathway, often called the school-to-prison pipeline, may be funneling adolescents with learning disabilities in vastly disproportionate numbers into the juvenile justice system (Federal Advisory Committee on Juvenile Justice, 2010).

\subsubsection{Mental health and substance abuse disorders}

Mental health problems and disorders are linked to later youthful offending behaviors and delinquency; though it is not clear if this link is direct or if these difficulties lead to other risk factors, poor decisionmaking, or the interaction of various other risks (Grisso, 2008; Shufelt \& Cocozza, 2006). Still, reviews have consistently found that children and adolescents who are involved with mental health services have a significantly higher risk for later juvenile court involvement 
(Rosenblatt, Rosenblatt, \& Biggs, 2000; Vander-Stoep, Evans, \& Taub, 1997).

In reviews that investigated the link from specific childhood mental health difficulties to juvenile court involvement a number of pathways have been established. Developmental studies have found behavioral and emotional problems to be predictive of later delinquency and substance abuse (Hawkins et al., 2000). Early childhood aggressive behaviors have been found predictive of later delinquent behaviors and activities, as well as attention and hyperactivity problems have been found linked to later high-risk taking and more violent offending behavior (Grisso, 2008). In addition, childhood depression and attention-deficit hyperactivity disorder have been found linked to later delinquency, evidenced through physical aggression and stealing behaviors (Wasserman et al., 2003).

For adolescents who are detained or incarcerated, a number of pathways from earlier mental health problems have been identified. Adolescent mental health and delinquent populations were found to be at higher risk for detention or incarceration with a diagnosis of alcohol problems or conduct disorder in middle school, reported use and abuse of substances, and being African-American or Hispanic a potential tie-in with the disproportionate minority confinement problem (Scott, Snowden, \& Libby, 2002). Other reviews have substantiated an increased risk of detainment for drug use and public mental health insurance coverage of the adolescents (Brunelle, Brochu, \& Cousineau, 2000; Wierson, Forehand, \& Frame, 1992). These two populations, adolescents with mental health problems and those involved in the juvenile justice system, often differ little across service delivery systems (Teplin et al., 2006).

\subsection{Comorbidity}

There is a strong link from these difficulties to serious youthful offending, often including detention and incarceration. These adolescent difficulties also become more complex and more difficult to unravel because of frequent comorbidities. Court-involved adolescents often have multiple disabilities and/or disorders occurring both over time and at the same time, a situation that may greatly compound the negative outcomes (Dembo, Wareham, Poythress, Meyers, \& Schmeidler, 2008). The comorbidity conundrum is an under-investigated phenomenon, but one that may strongly affect serious and chronic offenders, and those at risk for LWOP sentencing.

When such comorbid phenomena have been studied, difficult and complicated adolescent and family problems have come to light. In one investigation of delinquent youthful offenders, it was found that $32 \%$ had an identified special education disability, 39\% had an identified mental health disorder, $32 \%$ had an active substance abuse problem, $56 \%$ had been victims of maltreatment, and over $40 \%$ had two or more of these problems; with higher comorbid prevalence rates found for those who were detained or incarcerated (Mallett, 2009). In a similar review of a jurisdiction's mental health system and juvenile court, $20 \%$ of adolescents receiving mental health services had a recent arrest record, while $30 \%$ of adolescents arrested received mental health services (Rosenblatt et al., 2000). And in a study of the mental health problems of adolescents transferred from the juvenile to the criminal courts in Chicago, over 43\% of the youthful offenders had two or more psychiatric diagnoses (Washburn et al., 2008).

Of significant concern are the adolescents who are seriously emotionally disturbed, identified with multiple mental health disorders and related problems that continue into adulthood. This group almost always has contact with the juvenile justice system, represents up to $20 \%$ of youthful offenders within incarceration facilities, and continues to have offending problems and eventual involvement with the criminal courts (Cocozza \& Skowyra, 2000). It is estimated that one of every ten adolescents who are seriously emotionally disturbed has both an impairing mental health disorder and an active substance abuse problem; a dual diagnosis, which is particularly difficult to address in treatment (Chassin, 2008).

These comorbid difficulties are also common in youthful offenders who have committed homicide. Many of these offenders' backgrounds have included combinations of the following: mental health disorders, developmental delays, substance abuse, maltreatment, and severe family dysfunction (Fenderich, Mackesy-Amiti, Goldstein, Spunt, \& Brownstein, 1995; Heide, 2003; Heide et al., 2011; Hill-Smith, Hugo, Hughes, Fonagy, \& Hartman, 2002; Myers \& Scott, 1998; Zagar, Busch, Grove, \& Hughes, 2009). For some of these offenders, these difficulties were experienced during both childhood and adolescence, compounding the problems (Mallett, 2003).

\section{Rehabilitation of serious youthful offenders}

Detained and incarcerated serious youthful offenders struggle during the significant amounts of time they spend within juvenile institutions with the multitudes of difficulties that have been under discussion, all of which can be correlated with higher risk of recidivism in and out of placement (Rosenblatt et al., 2000). However, research over the past two decades has found ways to improve outcomes. Both institutional and community-based settings can provide programs that reduce the risk of serious youthful offending, sometimes by 20 to 30\% (Aos, Phipps, Barnoski, \& Lieb, 2001; Greenberg, 2008). Programs that are effective have a number of common components: supportive social contexts and authoritative adults, a focus on changing problem behaviors, and interventions to improve the adolescent's psychosocial maturity (Scott \& Steinberg, 2008). For most youthful offenders, there are opportunities to address these difficulties and disabilities during probation supervision, detention, and incarceration. It would be important in working with youthful offenders to identify as early as possible the risk and disability areas and to address these difficulties preventatively. It may be possible to divert many adolescents before the commission of a serious felony or homicide, thus triggering automatic transfer laws and the possibility of LWOP sentencing; in particular since most serious youthful offenders have a significant delinquent and offending past, including detention and incarceration (Heide, 2003; Howell, 2003; Redding, 2010).

\subsection{Detention reform}

The detention of youthful offenders is best limited to those who have committed a serious offense and who pose a clear danger to public safety due to a high risk of their reoffending. However, detaining and incarcerating youthful offenders in and of itself does little to improve delinquent behaviors or offending outcomes, and, in certain circumstances, it causes harm by negatively affecting adolescents and increasing their recidivism risk (Loughran et al., 2009; Winokur, Smith, Bontrager, \& Blankenship, 2008). However, when such institutional stays incorporate the identification of adolescent trauma, disability, and other problem areas, include subsequent rehabilitative efforts, and move away from a punitive framework, youthful offender outcomes can be significantly improved (Annie E. Casey Foundation, 2009; Greenberg, 2008).

It is critically important to identify, as early as possible, a youthful offender's disability problems or difficulties. A number of screening tools and instruments are available and are effective in identifying adolescent mental health problems and disorders (Massachusetts Youth Screening Instrument, Youth Level of Service/Case Management Inventory, Behavioral and Emotional Screen System, Diagnostic Interview Schedule for Children Version 4), substance abuse and disorders (Adolescent Substance Abuse Subtle Screening Instrument, Global Appraisal of Individual Need - Short Screen, Michigan Alcohol Screening Test), and trauma problems (Traumatic Events Screening Inventory, Child Welfare Trauma Screening Tool, Trauma Symptom Checklist for Children). In fact, studies of the effects stemming from 
the utilization of one of these mental health screening tools (the MAYSI-2) found that in nine detention centers in three states, staff increased efforts to obtain mental health services and suicide precautions for youth in the facilities (Models for Change, 2011). Unfortunately, this is far from the norm in such facilities (Sedlak \& McPherson, 2010).

Within the detention and incarceration facilities a number of specific programs and interventions have been found effective aggression replacement training, cognitive-behavioral therapy, and the Family Integrated Transitions Program. Aggression replacement training uses certain cognitive-behavioral techniques to identify anger triggers, improve behavioral skills, and increase youthful offenders' pro-social skills; cognitive-behavioral therapy focuses on skill building and step by step curriculum to affect change; and the Family Integrated Transitions Program uses a combination of interventions (Multi-systemic Therapy, relapse prevention, etc.) to address youthful offender's mental health and substance abuse problems and to ease transitions back to the community after detention facility release (Aos, 2004; Lipsey \& Landenberger, 2006).

\subsection{Incarceration reform}

Serious youthful offenders who are transferred to adult incarceration facilities have little hope for improved outcomes. Jails and prisons are violent and traumatizing places for many inmates, with high levels of physical assaults (Stephan \& Karberg, 2003; Wolff, Blitz, Shi, Siegel, \& Bachman, 2007). Difficulties encountered while incarcerated may impose new learned behaviors on prisoners, increasing antisocial activities because of the experience (Dodge \& Pettit, 2003).

There is more hope for serious youthful offenders within the juvenile justice system, supporting efforts for the juvenile courts to retain jurisdictional custody; or at least not without a thorough judicial review of what is in the best interests of the adolescent and the community. A majority of serious youthful offenders across the nation in the juvenile justice system are still in large "training school" type facilities (Livsey, Sickmund, \& Sladky, 2009). Such facilities generally provide little to no rehabilitative care for youthful offenders with disabilities, often do not meet the education - often special education - needs of the adolescents, and can be overcrowded and unsafe environments (Sedlak \& McPherson, 2010). Many, but not all, incarceration facilities use punitive approaches; however, recognition is growing that a rehabilitative approach better achieves important public policy goals of decreasing youthful offender recidivism and, subsequently, increasing community safety (Caldwell, Vitacco, \& Van Rybrock, 2006).

There is evidence that incarceration facilities that identify serious youthful offender problems and provide disability treatment services can have a significant impact on decreasing reoffending (Armeluis \& Andreassen, 2007; Garrido \& Morales, 2007; Greenwood \& Turner, 2009). Behavior contracting and programming, individual counseling, skill building (improving anger management skills, for example), group counseling, education, vocational training, and combinations of these services have shown some effectiveness as rehabilitative interventions. In addition, studies indicate that when such rehabilitative interventions are utilized, they must be well designed, of high quality, and of sufficient duration in order to have an impact (Lipsey, 2009; Weisz, Jensen-Doss, \& Hawley, 2006).

\subsection{Serious youthful offenders, homicide, and rehabilitation}

Many serious and violent juvenile offenders can be rehabilitated, including those adolescents who commit homicide (Heide et al., 2011). While the treatment efficacy literature is still not fully developed for the subset of serious youthful offenders who commit homicide, enough is known to discuss how to rehabilitate two groups. The first group includes those who are not long-term delinquent offenders and their homicide was often an isolated act of violence, with the victim being closely inter-related with the offender. Outcomes, when studied for this group, are quite positive with most not reoffending postprison release and successfully reintegrating with their families and communities; hence, rehabilitative efforts may not need to be focused on these young people (Benedeck, Cornwell, \& Staresina, 1989; Hillbrand, Alexander, Young, \& Spitz, 1999). However, the second group, those who are chronic or seriously delinquent and commit a homicide, struggle significantly with their post-prison readjustment and have high recidivism rates (Loeber et al., 2005; Toupin, 1993; Zagar, Busch, et al., 2009; Zagar, Isbell, et al., 2009).

Efforts are necessary for this second group in redirecting their futures away from a life of adult incarceration and possibly life sentences without parole. Many of these young people can be effectively rehabilitated within institutions which with they are placed (Kinscherff, 2012; Mendel, 2011). As discussed, changes are being made to detention, and in particular some juvenile incarceration facilities, to focus on treatment and rehabilitation and not solely punishment. These efforts should continue, along with minimizing the transfer of offenders to adult incarceration facilities (Fagan, 2008) where little rehabilitative programming is available and recidivism rates, post release, are very high (Pew Center on the States, 2011; Trulson, Haerle, DeLisi, \& Marquart, 2011).

When evaluated, treatment and rehabilitation has been found effective for many youthful offenders who have committed a homicide. In one review, the Texas Youth Commission, Capital Offender Treatment Program (2002) utilized many of the earlier discussed institutional facility changes in providing treatment to these young people and decreasing their reincarceration rate by $43 \%$ over a three-year postrelease time period. Specifically, rehabilitative programming recommended for this youthful offender group includes cognitive behavioral programming, trauma interventions, positive peer communities, mental health and substance abuse treatment, transition and reentry efforts, intensive and extended aftercare, and specialized educational and vocational programming (Agee, 1995; Lipsey, Howell, Kelly, Chapman, \& Carver, 2010; Mallett, 2013; Mears \& Aron, 2003).

\section{Adolescents sentenced to die in prison}

\subsection{Cruel and unusual punishment}

Though the law today allows a juvenile LWOP sentence only after an individualized sentencing decision finds the sanction proportional given the circumstances of the offense and mitigating factors, there is no guarantee that important evidence regarding the adolescent's family problems, learning deficiencies, mental health disorders, and other mitigating evidence is reviewed at trial. In a review of 53 juvenile offenders convicted of homicide and sentenced to death row (before Roper $v$. Simmons banned capital punishment for those under age 18), almost half (26) of the offenders' life histories or difficulties were not presented at trial, with an additional five juries that were informed only that the offender was a juvenile. In other words, no mitigating evidence was presented for a near majority of this death-row sentenced population. However, almost all of these adolescents had histories of maltreatment and trauma (many with brain damage), suffered from mental health problems, lived in poverty, and had significant school and academic problems, including developmental disabilities (Mallett, 2003). In a second review of 20 executed juveniles, similar outcomes were found in that nine had medically documented brain damage; however, only two of these adolescents' jury trials were presented with this mitigating evidence (American Bar Association, 2004). These study findings are disconcerting because while Williams requires an individualized sentencing decision including mitigating evidence before a LWOP determination, with the Supreme Court requiring mitigating evidence reviews for all death penalty determinations since 1976; it seems this right was not guaranteed for these adolescents on death row. 
There are related problems for these adolescent offenders. It has been strongly hypothesized that investigated and substantiated cases of maltreatment are just the identified portion of a most underreported phenomenon - with some estimates of maltreatment affecting perhaps over eight million of this country's children and adolescents, nearly ten-fold the official 2010 rate (Finkelhor, Ormrod, Turner, \& Hamby, 2005; U.S. Department of Health and Human Services, 2010). In addition, serious child and adolescent mental health problems, many times related to trauma, are often unidentified, or if known, lack appropriate community-based treatment options (Kessler et al., 2005; Substance Abuse and Mental Health Services Administration, 2008a). These experiences, including poor parenting, abuse and neglect, and mental health problems (including psychopathic traits), are predictors of adolescent violence and, for some, homicide (DeLisi \& Walters, 2011; Heide, 1999; Hill-Smith et al., 2002; Piquero, MacDonald, Dobrin, Daigle, \& Cullen, 2005).

\subsection{Constitutional but complicated}

While the Supreme Court's decision in Miller was a step forward in eliminating mandatory state LWOP sentences, this still allows the LWOP sentence after a review of mitigating and offense specific evidence. In addition, the scores of state laws that automatically transfer certain categories of youthful offenders to criminal court must be addressed; an LWOP sentence begins with this transfer. This constitutional right granted in Miller may still not be guaranteed if important mitigating evidence is not uncovered - which can be quite difficult in many circumstances - and reviewed. In light of whom the population of serious youthful offenders is in this country's detention and incarceration facilities, this Court decision does not go far enough in at least allowing the possibility of a parole hearing for all adolescents who are so LWOP sentenced.

In fact, if the present prognosticates the future, those currently serving juvenile LWOP sentences present a compelling argument. In a study of 1579 individuals around the country serving these sentences, the following was identified: nearly half $(47 \%)$ experienced physical abuse, including almost $80 \%$ of females; $21 \%$ were victims of sexual abuse, including $77 \%$ of females; $40 \%$ had been enrolled in special education classes; $84 \%$ had been suspended or expelled from school, including 53\% that were not enrolled in school at the time of the crime; $32 \%$ had been raised in public housing; and almost $20 \%$ were homeless, living with a friend, in a detention center, or a group home prior to incarceration. For this population sentenced to die in prison, changes occurred for those imprisoned for more than 30 years: over $67 \%$ completed high school or obtained a GED, and $71 \%$ had not been disciplined for their most recent three years (Nellis, 2012).

The law today does not eliminate juvenile LWOP sentences, thus allowing adolescents who commit homicide to be incarcerated until death. There is no available review of their status, behavior, development, maturity, or responsibility changes while incarcerated, not in 30 years, not in 40 years, not ever. It is impossible to know or accurately predict which offenders can be rehabilitated or become potentially useful members of society; but for those limited number of individuals whereby change is possible, leaving prison is not. For adolescents with significant maltreatment, trauma, family, mental health, and/or learning and academic problems (though more likely a comorbid amalgamation of these difficulties over time) to receive this sentence is a disproportionate and unjust outcome. While the crimes committed are serious, or in some cases heinous, who's to say that earlier interventions or preventative programming addressing these maltreatment, disability, and academic problems would not have diverted the adolescents' pathway. As reviewed earlier, many serious offending youth, including some who have committed homicide, have successfully rehabilitated. A just society takes responsibility for its members, particularly those so disadvantaged. Allowing the possibility of a parole hearing is a small, but important, option that should be available to adolescents who commit homicide and are sentenced to juvenile LWOP. More directly, a just society determines that a juvenile LWOP sentence is cruel and unusual punishment and holds it to be unconstitutional.

\section{References}

Administration for Children and Families (2011). Child maltreatment 2010. Washington, D.C.: U.S. Department of Health and Human Services.

Agee, V. L. (1995). Managing clinical programs for juvenile delinquents. In R. Mathias P. DeMuro, \& R. Allinson (Eds.), Managing delinquency programs that work (pp. 173-186). Laurel, MD: American Correctional Association.

American Bar Association (2004). Cruel and unusual punishment: The juvenile death penalty: Adolescence, brain development, and legal culpability. Washington D.C.: Juvenile Justice Center.

American Psychiatric Association (2000). Diagnostic and statistical manual of mental disorders IV - TR. Washington, D.C.: American Psychiatric Association Press.

Annie E. Casey Foundation (2009). Detention reform: An effective approach to reduce racial and ethnic disparities in juvenile justice. Baltimore, MD: The Annie E. Casey Foundation.

Aos, S. (2004). Washington state's family integrated transitions program for juvenile offenders: Outcome evaluation and benefit-cost analysis. Olympia, WA: Washington State Institute for Public Policy.

Aos, S., Phipps, P., Barnoski, R., \& Lieb, R. (2001). The comparative costs and benefits of programs to reduce crime (version 4.0). Olympia, WA: Washington State Institute for Public Policy.

Arata, C. A., Langhinrichsen-Rohling, J., Bowers, D., \& O'Brien, N. O. (2007). Differential correlates of multi-type maltreatment among urban youth. Child Abuse E' Neglect: The International Journal, 31, 393-415.

Armeluis, B. A., \& Andreassen, T. H. (2007). Cognitive-behavioural treatment for antisocial behavior in youth in residential treatment. Oslo, Norway: The Campbell Collaboration. Atkins v. Virginia, (2002) 536 U.S. 304.

Benedeck, E. P., Cornwell, D. G., \& Staresina, L. (1989). Treatment of the homicida adolescent. In E. P. Benedeck, \& D. G. Cornell (Eds.), Juvenile homicide (pp. 221-247). Washington, D.C.: American Psychiatric Press.

Brunelle, N., Brochu, S., \& Cousineau, M. (2000). Drug-crime relations among drugconsuming juvenile delinquents: A tripartite model. Contemporary Drug Problems, 27(4), 835-867.

Caldwell v. Mississippi, (1987) 472 U.S. 320.

Caldwell, M. F., Vitacco, M., \& Van Rybrock, G. J. (2006). Are violent delinquents worth treating? A cost benefit analysis. Journal of Research in Crime and Delinquency, 43 , $148-168$.

California v. Brown, (1976) 475 U.S. 1301.

Chassin, L. (2008). Juvenile justice and substance abuse. The Future of Children, 18(2), 165-184.

Cocozza, J., \& Skowyra, K. (2000). Youth with mental health disorders: Issues and emerging responses. Juvenile Justice Journal, 7(1), 3-13.

Degue, S., \& Widom, C. S. (2009). Does out-of-home placement mediate the relationship between child maltreatment and adult criminality? Child Maltreatment, 14(4) 344-355.

DeLisi, M., \& Walters, G. (2011). Multiple homicide as a function of prisonization and concurrent instrumental violence: Testing an interaction model - Research note. Crime and Delinquency, 47, 147-161.

Dembo, R., Wareham, J., Poythress, N., Meyers, K., \& Schmeidler, J. (2008). Psychosocial functioning problems over time among high-risk youth: A latent class transition analysis. Crime \& Delinquency, 54(4), 644-670.

Dodge, K. A., \& Pettit, G. S. (2003). A biopsychosocial model of the development of chronic conduct problems in adolescence. Developmental Psychology, 39, 349-371.

Eddings v. Oklahoma, (1982) 455 U.S. 104

Edmund v. Virginia, (1982) 458 U.S. 782.

Fagan, J. (2008). Juvenile crime and criminal justice: Resolving border disputes. The Future of Children, 18, 81-118.

Farrington, D. P., Loeber, R., \& Berg, M. T. (2012). Young men who kill: A prospective longitudinal examination from childhood. Homicide Studies, 16(2), 99-128.

Federal Advisory Committee on Juvenile Justice (2010). Annual report 2010. Washington D.C.: Office of Juvenile Justice and Delinquency Prevention, U.S. Department of Justice.

Fenderich, M., Mackesy-Amiti, M., Goldstein, P., Spunt, B., \& Brownstein, H. (1995) Substance involvement among juvenile murderers: Comparisons with older offenders based on interviews with prison inmates. International Journal of the Addictions, 30, 1363-1382.

Finkelhor, D., Ormrod, R., Turner, H., \& Hamby, S. L. (2005). The victimization of children and youth: A comprehensive, national survey. Child Maltreatment, 19(1), $5-25$

Furman v. Georgia, (1972) 408 U.S. 238.

Garrido, V., \& Morales, L. A. (2007). Serious (violent and chronic) juvenile offenders: A systematic review of treatment effectiveness in secure corrections. The Campbel Collaboration Reviews of Intervention and Policy Evaluations (CT-RIPE). Philadelphia PA: Campbell Collaboration.

Graham v. Florida, (2010) 560 U.S.

Green, S. T. (2005). Prosecutorial waiver into adult criminal court: A conflict of interests violation amounting to the states' legislative abrogation of juveniles' due process rights. Pennsylvania State Law Review, 110(148), 233-259.

Greenberg, P. (2008). Prevention and intervention programs for juvenile offenders. The Future of Children, 18(2), 185-210.

Greenwood, P., \& Turner, S. (2009). Overview of prevention and intervention programs for juvenile offenders. Victims \& Offenders, 4(4), 365-374. 
Gregg v. Georgia, (1976) 428 U.S. 153.

Griffin, P. (2011). Trying juveniles as adults: An analysis of state transfer laws and reporting. Washington, D.C.: Office of Juvenile Justice and Delinquency Prevention, Office of Justice Programs, U.S. Department of Justice.

Grisso, T. (2008). Adolescent offenders with mental disorders. The Future of Children, $18(2), 143-162$

Grogan-Kaylor, A., Ruffolo, M. C., Ortega, R. C., \& Clarke, J. (2008). Behavior of youth involved in the child welfare system. Child Abuse \& Neglect: The International Journal, $32,35-49$.

Hamilton, C. E., Falshaw, L., \& Browne, K. D. (2002). The link between recurrent maltreatment and offending behavior. International Journal of Offender Therapy and Comparative Criminology, 46, 75-94.

Hawkins, J. D., Herrenkohl, T. I., Farrington, D. P., Brewer, D., Catalano, R. F., Harachi, T. W., et al. (2000). Predictors of youth violence. Washington, D.C.: Office of Juvenile Justice and Delinquency Prevention, Office of Justice Programs, U.S. Department of Justice.

Heide, K. (1999). Young killers: The challenge of juvenile homicide. Thousand Oaks, CA: Sage.

Heide, K. (2003). Youth homicide: A review of the literature and blueprint for action. International Journal of Offender Therapy and Comparative Criminology, 38, 151-162.

Heide, K., Roe-Sepowitz, D., Solomon, E. P., \& Chan, H. C. (2011). Male and female juveniles arrested for murder: A comprehensive analysis of U.S. data by offender gender. International Journal of Offender Therapy and Comparative Criminology, 56(3), 356-384

Hillbrand, M., Alexander, J. W., Young, J. S., \& Spitz, R. T. (1999). Parracide: Characteristics of offenders and victims, legal factors, and treatment issues. Aggression and Violent Behavior, 4, 179-190.

Hill-Smith, A. J., Hugo, P., Hughes, P., Fonagy, P., \& Hartman, D. (2002). Adolescents murderers: Abuse and adversity in childhood. Journal of Adolescence, 25, 221-230.

Hitchcock v. Dubber, (1987) 481 U.S. 393.

Howell, J. C. (2003). Preventing \& reducing juvenile delinquency: A comprehensive framework. Thousand Oaks, CA: Sage Publications.

Human Rights Watch (2009). Juvenile offenders serving life without parole (rest of their lives 2009 update). New York, NY: Human Rights Watch.

Johnson v. Texas, (1993) 509 U.S. 350.

Johnson-Reid, M., \& Barth, R. P. (2000). From maltreatment report to juvenile incarceration: The role of child welfare services. Child Abuse \& Neglect, 24, 505-520.

Keleher, T. (2000). Racial disparities related to school zone tolerance policies. Testimony to the U.S. Commission on Civil Rights, February 18, 2000. Applied Research Center.

Kessler, R. C., Berglund, P., Demler, O., Jin, R., Merikangas, K. R., \& Walters, E. E. (2005) Lifetime prevalence and age-of-onset distributions of DSM-IV disorders in the national comorbidity survey replication. Archives of General Psychiatry, 62(6), 593-602.

Kinscherff, R. (2012). A primer for mental health practitioners working with youth involved in the juvenile justice system. Washington, D.C.: Technical Assistance Partnership for Child and Family Mental Health.

Lemmon, J. H. (2009). How child maltreatment affects dimensions of juvenile delinquency in a cohort of low-income urban males. Justice Quarterly, 16, 357-376.

Leone, P., \& Weinberg, L. (2010). Addressing the unmet educational needs of children and youth in the juvenile justice and child welfare systems. Washington, D.C.: Center for Juvenile Justice Reform, Georgetown University.

Lipsey, M. W. (2009). The primary factors that characterize effective interventions with juvenile offenders: A meta-analytic overview. Victims and Offenders, 4(4), 124-147.

Lipsey, M. W., Howell, J. C., Kelly, M. R., Chapman, G., \& Carver, D. (2010). Improving the effectiveness of juvenile justice programs. Washington, D.C.: Center for Juvenile Justice Reform, Georgetown University.

Lipsey, M. W., \& Landenberger, N. A. (2006). Cognitive-behavioural programs for juvenile and adult offenders: A meta-analysis of controlled intervention studies. Oslo, Norway: The Campbell Collaboration.

Livsey, S., Sickmund, M., \& Sladky, A. (2009). Juvenile residential facility census, 2004: Selected findings. Washington, D.C.: Office of Juvenile Justice and Delinquency Prevention, U.S. Department of Justice.

Lockett v. Ohio, (1978) 438 U.S. 586.

Loeber, R., \& Farrington, D. P. (2001). The significant concern of child delinquency. In R Loeber, \& D. P. Farrington (Eds.), Child delinquents: Development, intervention, and service needs (pp. 1-22). Thousand Oaks, CA: Sage Publications.

Loeber, R., Pardini, D., Homish, D. L., Wei, E. H., Crawford, A. M., Farrington, D. P., et al. (2005). The prediction of violence and homicide in young men. Journal of Consulting and Clinical Psychology, 73(6), 1074-1088.

Loughran, T., Mulvey, E., Schubert, C., Fagan, J., Pizuero, A., \& Losoya, S. (2009). Estimating a dose-response relationship between length of stay and future recidivism in serious juvenile offenders. Criminology, 47(3), 699-740.

Mallett, C. (2003). Socio-historical analysis of juvenile offenders on death row. Criminal Law Bulletin, 39(4), 455-468.

Mallett, C. (2009). Disparate juvenile court outcomes for disabled delinquent youth: A social work call to action. Child and Adolescent Social Work Journal, 26, 197-207.

Mallett, C. (2011). Seven things juvenile courts should know about learning disabilities. Reno, NV: National Council of Juvenile and Family Judges.

Mallett, C. (2013). Linking disorders to delinquency: Treating high-risk youth in the juvenile justice system. Boulder, CO: First Forum Press/Lynn Rienner Publishers.

Manly, J. T., Kim, J. E., Rogosch, F. E., \& Cicchetti, D. (2001). Dimension of child maltreatment and children's adjustment: Contributions of developmental timing and subtype. Development and Psychopathology, 13, 759-782.

Matta-Oshima, K. M., Huang, J., Jonson-Reid, M., \& Drake, B. (2010). Children with disabilities in poor households: Association with juvenile and adult offending. Socia Work Research, 34(2), 102-113.
Maxfield, M. G., Weiler, B. L., \& Widom, C. S. (2000). Comparing self-reports and official records of arrest. Journal of Quantitative Criminology, 16(1), 87-110.

Mears, D. P., \& Aron, L. Y. (2003). Addressing the needs of youth with disabilities in the juvenile justice system: The current state of knowledge. Washington, D.C.: Urban Institute, Justice Policy Center.

Mendel, R. (2011). No place for kids: The case for reducing juvenile incarceration. Baltimore, MD: The Annie E. Casey Foundation.

Miller v. Alabama, (2012) 567 U.S.

Models for Change (2011). Does mental health screening fulfill its promise? Models for Change: Systems Reform in Juvenile Justice. Chicago, IL: The John D. and Catherine T. MacArthur Foundation.

Myers, W., \& Scott, K. (1998). Psychotic and conduct disorder symptoms in juvenile murderers. Homicide Studies, 2, 160-175.

Nellis, A. (2012). The lives of juvenile lifers: Findings from a national survey. Washington, D.C.: The Sentencing Project.

New Freedom Commission on Mental Health (2003). Achieving the promise: Transforming mental health care in America, final report. Washington, D.C.: U.S. Department of Health and Human Services.

Pew Center on the States (2011). State of recidivism: The revolving door of America's prisons. Washington, D.C.: The Pew Charitable Trusts.

Piquero, A., MacDonald, J., Dobrin, A., Daigle, L., \& Cullen, F. (2005). Self-control, violent offending, and homicide victimization: Assessing the general theory of crime. Journal of Quantitative Criminology, 21, 55-71.

Proffitt v. Florida, (1976) 428 U.S. 242.

Puzzanchera, C., \& Kang, W. (2011). Easy access to the FBI's supplemental homicide reports: 1980-2009. Washington, D.C.: Office of Juvenile Justice and Delinquency Prevention, U.S. Department of Justice.

Redding, R. E. (2010). Juvenile transfer laws: An effective deterrent to delinquency? Washington, D.C.: Office of Juvenile Justice and Delinquency Prevention, Office of Justice Programs, U.S. Department of Justice.

Roe-Sepowitz, D. E. (2009). Comparing male and female juveniles charged with homicide: Child maltreatment, substance abuse and crime details. Journal of Interpersonal Violence, 24, 601-617.

Roper v. Simmons, (2005) 543 U.S. 551

Rosenblatt, J. A., Rosenblatt, A. R., \& Biggs, E. E. (2000). Criminal behavior and emotional disorder: Comparing youth served by the mental health and juvenile justice systems. The Journal of Behavioral Health Services \& Research, 27(2), 227-237.

Scott, M., Snowden, L., \& Libby, A. M. (2002). From mental health to juvenile justice: What factors predict this transition? Journal of Child and Family Studies, 11(3), 299-311.

Scott, E. S., \& Steinberg, L. (2008). Adolescent development and the regulation of youth crime. The Future of Children, 18(2), 18-33.

Sedlak, A. J., \& McPherson, K. (2010). Survey of youth in residential placement: Youth's needs and services. Washington, D.C.: Westat Corporation.

Shufelt, J. L., \& Cocozza, J. J. (2006). Youth with mental health disorders in the juvenile justice system: Results from a multi-state prevalence study. Delmar, NY: National Center for Mental Health and Juvenile Justice.

Smith, C. A. \& Thornberry, T. O. (1995). The relationship between childhood maltreatment and adolescent involvement in delinquency. Criminology, 33(4), 451-481.

Snyder, H. N. (1998). Serious, violent, and chronic juvenile offenders: An assessment of the extent of and trends in officially recognized serious criminal behavior in a delinquent population. In R. Loeber, \& D. P. Farrington (Eds.), Serious and violent juvenile offenders: Risk factors and successful interventions (pp. 440-472). Thousand Oaks, CA: Sage Publications.

Stephan, J. J., \& Karberg, J. C. (2003). Census of state and federal correctional facilities, 2000. Washington, D.C.: Bureau of Justice Statistics, Office of Justice Programs, U.S. Department of Justice.

Substance Abuse and Mental Health Services Administration (2008a). Trends in substance use, dependence or abuse, and treatment among adolescents: 2002-2007. Washington, D.C.: Office of Applied Studies, U.S. Department of Health and Human Services.

Substance Abuse and Mental Health Services Administration (2008b). Mental health, United States, 2008. Washington, D.C.: Center for Mental Health Services, U.S. Department of Health and Human Services.

Substance Abuse and Mental Health Services Administration (2010). Results from the 2009 National Survey on Drug Use and Health: Mental health findings. Washington, D.C.: Office of Applied Studies, U.S. Department of Health and Human Services.

Sum, A., Khatiwada, I., McLaughlin, J., \& Palma, S. (2009). The consequences of dropping out of high school: Joblessness and jailing for high school dropouts and the high cost to taxpayers. Boston, MA: Center for Labor Market Studies, Northeastern University.

Teplin, L., Abram, K., McClelland, G., Mericle, A., Dulcan, M., \& Washburn, D. (2006). Psychiatric disorders of youth in detention. Washington, D.C.: Office of Justice Programs, Office of Juvenile Justice and Delinquency Prevention, U.S. Department of Justice.

Texas Youth Commission, Capital Offender Treatment Program (2002). Texas youth handbook. Austin, TX: Texas Youth Commission.

Toupin, J. (1993). Adolescent murderers: Validation of a typology and study of their recidivism. In A. V. Wilson (Ed.), Homicide: The victim/offender connection (pp. 79-94). New York: Guilford.

Trulson, C. R., Haerle, D. R., DeLisi, M., \& Marquart, J. W. (2011). Blended sentencing early release, and recidivism of violent institutionalized delinquents. The Prison Journal, 91(3), 255-278.

U.S. Department of Education (2010). 29th annual report to Congress on the implementation of the Individuals with Disabilities Education Act, 2007 (table 1-9). Washington, D.C.: Office of Special Education and Rehabilitative Services, Office of Special Education Programs.

U.S. Department of Health and Human Services (2010). Child maltreatment 2008. Washington, D.C.: U.S. Government Printing Office. 
U.S. Surgeon General (2001). Report on the surgeon general's conference on children's mental health. Washington, D.C.: U.S. Department of Health and Human Services.

Vander-Stoep, A., Evans, C., \& Taub, J. (1997). Risk of juvenile justice system referral among children in a public mental health system. Journal of Mental Health Administration, 24, 428-442.

Verrecchia, P. J., Fetzer, M. D., Lemmon, J. H., \& Austin, T. L. (2010). An examination of direct and indirect effects of maltreatment dimensions and other ecological risk on persistent youth offending. Criminal Justice Review, 35(2), 220-243.

Wang, X., Blomberg, T. G., \& Li, S. D. (2005). Comparison of the educational deficiencies of delinquent and nondelinquent students. Evaluation Review A Journal of Applied Social Research, 29(4), 291-312.

Washburn, J., Teplin, L., Voxx, L., Simon, C., Abram, K., \& McClelland, G. (2008). Psychiatric disorders among detained youths: A comparison of youths processed in juvenile court and adult criminal court. Psychiatric Services, 59(9), 965-973.

Wasserman, G. A., Keenan, K., Tremblay, R. E., Cole, J. D., Herrenkohl, T. I., Loeber, R. et al. (2003). Risk and protective factors of child delinquency. Washington, D.C.: Office of Juvenile Justice and Delinquency Prevention, U.S. Department of Justice.

Weisz, J. R., Jensen-Doss, A., \& Hawley, K. M. (2006). Evidence-based youth psychotherapies versus usual clinical care. The American Psychologist, 61(7), 671-689.
Widom, C. S., \& Maxfield, M. (2001). An update on the "cycle of violence". Washington, D.C.: National Institute of Justice, U.S. Department of Justice.

Wierson, M., Forehand, R. L., \& Frame, C. L. (1992). Epidemiology and treatment of mental health problems in juvenile delinquents. Advanced Behavioral Research and Therapy, 14, 93-120.

Williams v. Taylor, (2000) 529 U.S. 362.

Winokur, K. P., Smith, A., Bontrager, S. R., \& Blankenship, J. L. (2008). Juvenile recidivism and length of stay. Journal of Criminal Justice, 36, 126-137.

Wolff, N., Blitz, C., Shi, J., Siegel, J., \& Bachman, R. (2007). Physical violence inside prisons: Rates of victimization. Criminal Justice and Behavior, 34, 588-599.

Woodson v. California, (1976) 428 U.S. 280.

Yun, I., Ball, J. D., \& Lim, H. (2011). Disentangling the relationship between child maltreatment and violent delinquency: Using a nationally representative sample. Journal of Interpersonal Violence, 26(1), 88-110.

Zagar, R. J., Busch, K. G., Grove, W. M., \& Hughes, J. R. (2009a). Homicidal adolescents: A replication. Psychological Reports, 104, 17-45.

Zagar, R. J., Isbell, S. A., Busch, K. G., \& Hughes, J. R. (2009b). An empirical theory of the development of homicide within victims. Psychological Reports, 104, 199-245. 